\title{
HEAVY METALS IN OXISOLS AMENDED WITH BIOSOLIDS AND CROPPED WITH MAIZE IN A LONG-TERM EXPERIMENT
}

\author{
Katarzyna Wójcik Oliveira; Wanderley José de Melo*; Gener Tadeu Pereira; Valéria Peruca de \\ Melo; Gabriel Maurício Peruca de Melo \\ UNESP/FCAV - Depto. de Tecnologia, Campus de Jaboticabal, Via de Acesso Prof. Paulo Donato Castellane, \\ km 5 - 14884-900 - Jaboticabal, SP - Brasil. \\ *Corresponding author <wjmelo@fcav.unesp.br>
}

\begin{abstract}
Biosolids comprise organic matter and plant nutrients, but are also a source of heavy metals hazardous to soils, plants and humans. The aim of this work was to evaluate accumulation, movement in the soil profile and availability to maize plants of heavy metals in two oxisols amended with biosolids for five years. The experiment was carried out in Jaboticabal, SP, Brazil, under field conditions, using a split-plot design. Biosolids were added to the soils at four different rates, 0.0 (control with mineral fertilization), 2.5; 5.0 and $10.0 \mathrm{t} \mathrm{ha}^{-1}$, dry weight basis, annualy for three years. In the fourth and fifth years, the $2.5 \mathrm{t} \mathrm{ha}^{-1}$ treatment rate was increased to $20.0 \mathrm{t} \mathrm{ha}^{-1}$. In the fifth year, soil samples were collected at $0-20$ and 20-40 cm depths and analyzed for $\mathrm{Cu}, \mathrm{Ni}, \mathrm{Mn}, \mathrm{Pb}$ and $\mathrm{Zn}$ total and extractable (Mehlich 1) contents. Biosolids increased the concentration of $\mathrm{Ni}$ and $\mathrm{Zn}$ in the Typic Eutrorthox, and of $\mathrm{Ni}, \mathrm{Pb}, \mathrm{Zn}$ and $\mathrm{Cu}$ in the Typic Haplorthox, but values did not exceed critical limits established by legislation. The elements generally accumulated in the 0 $20 \mathrm{~cm}$ depth. Lead and $\mathrm{Ni}$ concentrations in grains were below detection limits. In general, heavy metals contents in maize plants were not affected by application of biosolids. Mehlich 1 extractant was not efficient in predicting the availability of $\mathrm{Ni}, \mathrm{Mn}$, and $\mathrm{Pb}$ to maize plants.

Key words: Mehlich 1, sewage sludge, maize, metal availability

\section{METAIS PESADOS EM LATOSSOLOS TRATADOS COM BIOSSÓLIDO E CULTIVADOS COM MILHO EM EXPERIMENTO DE LONGA DURAÇÃO}

\begin{abstract}
RESUMO: O biossólido contém em sua composição matéria orgânica e nutrientes das plantas, mas também metais pesados danosos para solos, plantas e a saúde humana. O objetivo deste trabalho foi avaliar o acúmulo de metais pesados e sua mobilidade no perfil do solo, assim como a disponibilidade para plantas de milho cultivadas em Latossolo Vermelho distrófico (LVd) e Latossolo Vermelho eutroférrico (LVef) tratados com doses crescentes de biossólido durante cinco anos. O experimento foi conduzido em Jaboticabal, SP, Brasil, em condições de campo, utilizando-se delineamento de parcelas subdivididas com cinco repetições. Foram testadas quatro doses de biossólido: 0,$0 ; 2,5 ; 5,0 \mathrm{e} 10,0 \mathrm{t} \mathrm{ha}^{-1}$ (base seca) nos três primeiros anos. A partir do quarto ano a dose 2,5 foi substituída por 20,0 $\mathrm{tha}^{-1}$. No quinto ano de experimentação amostras de solo foram obtidas nas profundidades $0-20$ e $20-40 \mathrm{~cm}$ e analisadas para totais e extraíveis (Mehlich 1) de $\mathrm{Cu}, \mathrm{Mn}, \mathrm{Ni}, \mathrm{Pb}$ e Zn. O biossólido aumentou os teores de $\mathrm{Ni}$ e $\mathrm{Zn}$ no LVef e Ni, $\mathrm{Pb}, \mathrm{Zn}$ e Cu no LVd, mas os valores não ultrapassaram os níveis críticos legais. Os elementos geralmente acumularam-se na profundidade $0-20 \mathrm{~cm}$ em ambos os solos. Os teores de Pb e Ni nos grãos ficaram abaixo do limite de detecção da metodologia empregada. As concentrações de metais pesados na planta geralmente não foram afetados pela adição de biossólido. $\mathrm{O}$ extrator Mehlich 1 não foi eficiente para avaliar a disponibilidade de $\mathrm{Ni}, \mathrm{Mn}$ e $\mathrm{Pb}$ para planta de milho.

Palavras-chave: Mehlich 1, lodo de esgoto, milho, fitodisponibilidade
\end{abstract}

\section{INTRODUCTION}

Biosolids are residues from domestic and industrial wastewater treatments. Increasing costs of commercial fertilizers and large amounts of biosolids produced worldwide has made cropland application of this residue an attractive disposal option. Chemical and biological composition of biosolids depends on the wastewater com- position (Melo, 2002). Usually, it is rich in organic matter and plant nutrients such as N, P and Ca (Hue, 1988), and can improve soil physical and chemical properties, such as porosity, aggregate stability, bulk density, water movement and retention (Silveira et al., 2003), and soil fertility. In the tropics, where soils are generally poor in minerals with high cation exchange capacity (CEC) and in organic matter $(\mathrm{OM})$, biosolids could be an important 
soil amendment (Melo, 2002). On the other hand, biosolids contain hazardous constituents, such as heavy metals, and may cause soil and water pollution and toxicity to crops, animals and humans through the trophic chain (Mc Brige, 1995). Metal concentrations in biosolids vary widely, depending on the origin of the sludge and on the processes of treatment of sewage sludge (Mattigod \& Page, 1983).

Total contents of heavy metals in different plants and in different plant parts vary considerably. Most vegetative parts of plants, especially leaves, have higher heavy metal contents than seeds, nuts and fruits. Even when high rates of heavy metals are added to soils by biosolids application, the uptake of such metals by plants represent less than $1.0 \%$ of the total applied to the soil (Chang et al., 1984). Many methods are used to estimate heavy metals availability to plants in biosolids-amended soils, e.g. extraction with acid solutions $\left(0.1 \mathrm{~mol} \mathrm{~L}^{-1} \mathrm{HCl}\right.$ and Mehlich 1), with chelating agents (DTPA), or with acid and chelating agents (Mehlich 3). The objective of this work was evaluating heavy metal accumulation and movement in two soil profiles and to determine their phytoavailability to maize plants when the soils were amended with biosolids for five years.

\section{MATERIAL AND METHODS}

The experiment was carried out in a split-plot design field trial, on two soils (Typic Haplorthox (TH) and Typic Eurtrorthox (TE)), in Jaboticabal, SP, Brazil (21 $1^{\circ} 15^{\prime} 20^{\prime \prime} \mathrm{S}, 48^{\circ} 19^{\prime} 02^{\prime \prime} \mathrm{W}, 579 \mathrm{~m}$ altitude), from 1997 to 2002. The levels of biosolids application were: 0.0 (control, no biosolids, but with mineral fertilization according to soil analysis), 2.5, 5.0 and $10 \mathrm{t} \mathrm{ha}^{-1},(\mathrm{n}=5)$ dry weight basis, in the first three years. To increase the rate of heavy metals added to the soil from the fourth year the 2.5 rate was replaced by $20.0 \mathrm{t} \mathrm{ha}^{-1}$, using the same plots. Therefore, the accumulated amounts of biosolids over five years were $0.0 ; 25.0 ; 47.5$ and $50.0 \mathrm{t} \mathrm{ha}^{-1}$. Chemical properties of the two soils during the experimental period are shown in Tables 1 and 2.

Biosolids (Table 3) were obtained from the sewage treatment plant operated by SABESP in Barueri, Great São Paulo.

Total $\mathrm{N}$ concentration in biosolids was determined by the micro-Kjeldhal method; organic-C by wet oxidation; $\mathrm{K}$ by flame photometry; $\mathrm{P}$ by vanado-molybdate spectrophotometric method; and $\mathrm{Ca}, \mathrm{Mg}, \mathrm{Fe}, \mathrm{Cu}, \mathrm{Mn}$, $\mathrm{Zn}, \mathrm{Ni}, \mathrm{Cd}, \mathrm{Cr}$ and $\mathrm{Pb}$ by digestion with $\mathrm{HNO}_{3}+\mathrm{H}_{2} \mathrm{O}_{2}+\mathrm{HCl}$ (USEPA, 1986), followed by atomic absorption spectrophotometric analysis of the digest.

In the 1997/98 growing season, the area was ploughed and harrowed, and then $2.5 \mathrm{t} \mathrm{ha}^{-1}$ of dolomitic limestone were applied to raise base saturation to $70 \%$, following recommendation of Raij et al. (1996). Thirty days after liming, plots were marked out, each with a total area of $54 \mathrm{~m}^{2}\left(28,8 \mathrm{~m}^{2}\right.$ of useful area), including six, $10-\mathrm{m}$ long planted lines, spaced $0.90 \mathrm{~m}$. The two external lines and $1.0 \mathrm{~m}$ at the end of each planted line were used as plot frames; one of the two central lines was used for evaluation of grain production and the other for plant sampling.

Biosolids were spread on the soil surface and incorporated into the top $10 \mathrm{~cm}$ layer with a rotary hoe in the first year, and with a light harrowing in the last four years. Treatments receiving biosolids also received supplementary K and P, when necessary (Tables 4 and 5). The mineral fertilizer was applied in the plough furrow.

Table 1 - Chemical properties of a Typic Eutrorthox during five years of experimentation.

\begin{tabular}{lcccccccccc}
\hline Year & $\mathrm{pH} \mathrm{CaCl}_{2}$ & $\mathrm{OM}$ & $\mathrm{P}_{\mathrm{resin}}$ & $\mathrm{K}^{+}$ & $\mathrm{Ca}^{2+}$ & $\mathrm{Mg}^{2+}$ & $\mathrm{H}+\mathrm{Al}$ & $\mathrm{SB}$ & $\mathrm{CEC}$ & $\mathrm{V}$ \\
\hline $1997 / 98$ & 5.7 & 34 & 67 & 4.9 & 42 & 19 & 22 & 66 & 87 & 75 \\
$1998 / 99$ & 5.4 & 32 & 62 & 4.7 & 38 & 17 & 26 & 60 & 85 & 71 \\
$1999 / 00$ & 5.3 & 26 & 60 & 4.2 & 32 & 18 & 30 & 54 & 84 & 63 \\
$2000 / 01$ & 5.3 & 28 & 61 & 4.5 & 39 & 14 & 34 & 58 & 92 & 63 \\
$2001 / 02$ & 5.2 & 24 & 67 & 4.1 & 41 & 14 & 38 & 59 & 82 & 72 \\
\hline
\end{tabular}

Table 2 - Chemical properties of a Typic Haplorthox soil during five years of experimentation.

\begin{tabular}{lcccccccccc}
\hline Year & $\mathrm{pH} \mathrm{CaCl}_{2}$ & $\mathrm{OM}$ & $\mathrm{P}_{\mathrm{resin}}$ & $\mathrm{K}^{+}$ & $\mathrm{Ca}^{2+}$ & $\mathrm{Mg}^{2+}$ & $\mathrm{H}+\mathrm{Al}$ & $\mathrm{SB}$ & $\mathrm{CEC}$ & $\mathrm{V}$ \\
\hline $1997 / 98$ & 5.7 & 20 & 44 & 2.2 & 26 & 11 & 16 & 39 & 55 & 71 \\
$1998 / 99$ & 6.1 & 18 & 47 & 1.7 & 35 & 10 & 15 & 47 & 62 & 75 \\
$1999 / 00$ & 5.4 & 16 & 43 & 1.6 & 20 & 10 & 19 & 32 & 51 & 71 \\
$2000 / 01$ & 5.0 & 16 & 71 & 2.3 & 25 & 9 & 29 & 36 & 66 & 55 \\
$2001 / 02$ & 5.1 & 24 & 54 & 4.8 & 23 & 10 & 38 & 38 & 76 & 50 \\
\hline
\end{tabular}


Table 3 - Chemical composition of the biosolids used during the five years of experimentation.

\begin{tabular}{|c|c|c|c|c|c|c|}
\hline Element & Unit & $1997 / 1998$ & 1998/1999 & $1999 / 2000$ & $2000 / 2001$ & $2001 / 2002$ \\
\hline Nitrogen & $\mathrm{g} \mathrm{kg}^{-1}$ & 6.40 & 37.31 & 28.72 & 28.94 & 36.75 \\
\hline Phosphorus & $\mathrm{g} \mathrm{kg}^{-1}$ & 3.32 & 11.30 & 17.41 & 15.58 & 15.54 \\
\hline Potassium & $\mathrm{g} \mathrm{kg}^{-1}$ & 0.97 & 1.70 & 1.47 & 1.85 & 2.74 \\
\hline Manganese & $\mathrm{mg} \mathrm{kg}^{-1}$ & 228 & 294 & 257 & 263 & 287 \\
\hline Zinc & $\mathrm{mg} \mathrm{kg}^{-1}$ & 1800 & 3810 & 2328 & 1745 & 2354 \\
\hline Copper & $\mathrm{mg} \mathrm{kg}^{-1}$ & 664 & 551 & 660 & 719 & 627 \\
\hline Nickel & $\mathrm{mg} \mathrm{kg}^{-1}$ & 268 & 595 & 360 & 354 & 350 \\
\hline Lead & $\mathrm{mg} \mathrm{kg}^{-1}$ & 152 & 371 & 180 & 171 & 155 \\
\hline
\end{tabular}

Table 4 - Mineral fertilizations on Typic Haplorthox soil during five years of experimentation.

\begin{tabular}{|c|c|c|c|c|c|c|c|}
\hline \multirow{2}{*}{ Year } & \multirow{2}{*}{ Treatment } & \multicolumn{2}{|c|}{$\mathrm{N}$} & \multicolumn{2}{|c|}{$\mathrm{P}_{2} \mathrm{O}_{5}$} & \multicolumn{2}{|c|}{$\mathrm{K}_{2} \mathrm{O}$} \\
\hline & & Sowing & Dressed & Sowing & Dressed & Sowing & Dressed \\
\hline & & - - n & 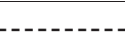 & - - - & - - & 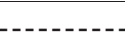 & - \\
\hline \multirow{4}{*}{$1997 / 98$} & $\mathrm{~T}$ & --- & --- & --- & --- & --- & --- \\
\hline & D1 & --- & --- & 50 & -- & 29 & --- \\
\hline & D2 & --- & --- & 44 & --- & 26 & --- \\
\hline & D3 & --- & --- & 33 & --- & 20 & --- \\
\hline \multirow[t]{4}{*}{$1998 / 99$} & $\mathrm{~T}$ & 16.7 & 60 & 30 & --- & 30 & --- \\
\hline & D1 & --- & -- & -- & -- & 25 & --- \\
\hline & D2 & --- & --- & --- & --- & 20 & --- \\
\hline & D3 & --- & --- & --- & --- & 10 & --- \\
\hline \multirow[t]{4}{*}{$1999 / 00$} & $\mathrm{~T}$ & 30 & 110 & 50 & --- & 50 & 40 \\
\hline & D1 & --- & --- & --- & --- & 46 & 40 \\
\hline & D2 & --- & --- & --- & --- & 41 & 40 \\
\hline & D3 & --- & --- & --- & --- & 32 & 40 \\
\hline \multirow[t]{4}{*}{$2000 / 01$} & $\mathrm{~T}$ & 30 & 120 & 50 & --- & 50 & 40 \\
\hline & D1 & -- & --- & -- & -- & 5 & 40 \\
\hline & D2 & --- & --- & 32 & --- & 39 & 40 \\
\hline & D3 & --- & --- & 2 & --- & 28 & 40 \\
\hline \multirow[t]{4}{*}{$2001 / 02$} & $\mathrm{~T}$ & 30 & 140 & 70 & --- & 50 & 40 \\
\hline & D1 & --- & --- & --- & --- & --- & 40 \\
\hline & D2 & --- & --- & --- & --- & 34 & 40 \\
\hline & D3 & --- & --- & --- & --- & 17 & 40 \\
\hline
\end{tabular}

T-Control treatment; D1-treatment with 2.5 or $20 \mathrm{t} \mathrm{ha}^{-1}$ of biosolids; D2- treatment with $5.0 \mathrm{t}^{-1} \mathrm{a}^{-1}$ of biosolids; D3- treatment with $10.0 \mathrm{t}$ ha $^{-1}$ of biosolids.

The control treatment received mineral fertilization (Tables 4 and 5). The dressed fertilization was done 45 days after sowing on the control treatment $(140 \mathrm{~kg} \mathrm{~N}$ $\mathrm{ha}^{-1}$ ). The test plant in the fifth year was maize (Zea mays L.), double hybrid Agromen 3150, at 5-7 plants $\mathrm{m}^{-1}$ (about 55,000 plants $\mathrm{ha}^{-1}$ ).

For the evaluation of the heavy metal concentrations in the plants, samples of five plants were taken from each plot 100 days after sowing, plants being cut just above the soil surface. The grains were harvested 120 days after sowing from all the plants in the line, dried at $65^{\circ} \mathrm{C}$ (forced air), then ground. An extract was prepared from nitric-perchloric acid digestion (Bataglia et al., 1983).

Soil samples $(0-20 \mathrm{~cm}$ and $20-40 \mathrm{~cm}$ layers $)$ were collected 60 days after sowing; 12 single samples in the useful area of each plot obtained at $10 \mathrm{~cm}$ by the side of the plants out of the line in which the mineral fertilizer was applied. Samples were air dried and sieved $(2 \mathrm{~mm})$. Total contents of heavy metals were determined in the extracts obtained by digestion with $\mathrm{HNO}_{3}+\mathrm{H}_{2} \mathrm{O}_{2}+\mathrm{HCl}$ (USEPA, 1986). Concentrations of heavy metals (Cu, Ni, $\mathrm{Mn}, \mathrm{Pb}, \mathrm{Zn}$ ) were determined in the extracts by atomic absorption spectrometry. 
Tukey's test, $(\alpha=0.05)$, was used for comparison of means when the $\mathrm{F}$ test was significant. The correlation coefficients (r) between metals extracted from soil by Mehlich 1 and amounts uptaken by maize plants (grain and shoots) were calculated.

\section{RESULTS AND DISCUSSION}

\section{Total heavy metals content and movement in soil}

Total $\mathrm{Ni}, \mathrm{Pb}, \mathrm{Zn}$ and $\mathrm{Cu}(0-20 \mathrm{~cm})$ and $\mathrm{Ni}, \mathrm{Pb}$, $\mathrm{Cu}(20-40 \mathrm{~cm})$ concentrations increased with increasing rates of biosolids, while Mn concentration was not affected in the TH. Martins et al. (2003) and Oliveira \& Mattiazzo (2001) also observed increasing $\mathrm{Cu}$ and $\mathrm{Zn}$ concentrations with increasing rates of biosolids in the $0-20 \mathrm{~cm}$ depth of soil.

Increasing concentrations of $\mathrm{Zn}$ were observed in the two depths, Mn at $20-40 \mathrm{~cm}$ and $\mathrm{Ni}$ at $0-20 \mathrm{~cm}$ in TE. None of the values found for the heavy metals exceeded the critical limits permitted for agricultural use of biosolids according to CETESB (1999) and USEPA (1995). Marchiori Jr. (2002) and Oliveira (2000) recorded similar results.

$\mathrm{Cu}, \mathrm{Zn}$ and $\mathrm{Ni}$ added to soils with biosolids tended to remain in the 0-20 cm layer (Table 6). For $\mathrm{Pb}$ and $\mathrm{Mn}$ there were differences between the depths 0-20 and $20-40 \mathrm{~cm}$, suggesting low mobility of these elements when added to the soil through biosolids. Sidle et al. (1976) found that more than $93 \%$ of all heavy metals applied over a 2-yr period were accumulated in the surface soil. Parker et al. (1978) reported that more than $95 \%$ of $\mathrm{Zn}$ and $\mathrm{Cu}$ remained in the $0-25 \mathrm{~cm}$ layer of soil. Anderson \& Nilson (1972) showed that practically all the $\mathrm{Mn}, \mathrm{Zn}, \mathrm{Cu}, \mathrm{Ni}, \mathrm{Co}$, $\mathrm{Cr}, \mathrm{Pb}, \mathrm{Cd}, \mathrm{Hg}$, As and Se remained in the upper 0-20 cm of the soil 12 years after adding $84 \mathrm{tha}^{-1}$ of sludge. Boswel (1975) found that very little $\mathrm{Zn}$ moved deeper than $15 \mathrm{~cm}$ in a clay loam soil. The accumulation of $\mathrm{Zn}, \mathrm{Cu}, \mathrm{Ni}$ and $\mathrm{Pb}$ in the top layer of the soil can be attributed to the high affinity of the metals to organic matter (McGrath \& Lane, 1989). The highest concentrations of metals were observed for $\mathrm{Cu}, \mathrm{Mn}$ and $\mathrm{Zn}$ in the TE soil. Oliveira \& Mattiazzo (2001) also found $\mathrm{Cu}$ and $\mathrm{Zn}$ at the highest concentrations accumulated in soil among all the analysed elements.

TE had higher metal contents than TH. This soil has higher organic matter (Table 1) and clay amounts than the TH. Heavy metals may be strongly adsorbed to the soil organic and mineral colloids such as clay, iron hydroxides and manganese oxides and to soil OM (Chaney \& Giordano, 1977).

Table 5 - Mineral fertilizations on Typic Eutrorthox soil during five years of experimentation.

\begin{tabular}{|c|c|c|c|c|c|c|c|}
\hline \multirow{2}{*}{ Year } & \multirow{2}{*}{ Treatment } & \multicolumn{2}{|c|}{$\mathrm{N}$} & \multicolumn{2}{|c|}{$\mathrm{P}_{2} \mathrm{O}_{5}$} & \multicolumn{2}{|c|}{$\mathrm{K}_{2} \mathrm{O}$} \\
\hline & & Sowing & Dressed & Sowing & Dressed & Sowing & Dressed \\
\hline & & - & - & - & (-....... & - & - \\
\hline \multirow{4}{*}{$1997 / 98$} & $\mathrm{~T}$ & --- & --- & --- & 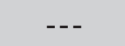 & --- & --. \\
\hline & D1 & -- & -- & 50 & --. & 29 & --- \\
\hline & D2 & --- & --- & 44 & --- & 26 & --- \\
\hline & D3 & --- & --- & 33 & --- & 20 & --- \\
\hline \multirow[t]{4}{*}{ 1998/99 } & $\mathrm{T}$ & 15 & 61 & 30 & --- & 30 & --- \\
\hline & D1 & --- & --- & --- & --- & 25 & --- \\
\hline & D2 & --- & --- & --- & --- & 20 & --- \\
\hline & D3 & --- & --- & -- & -- & 10 & --- \\
\hline \multirow[t]{4}{*}{$1999 / 00$} & $\mathrm{~T}$ & 30 & 110 & 50 & -.- & 50 & 40 \\
\hline & D1 & --- & --- & --- & --- & 46 & 40 \\
\hline & D2 & --- & --- & --- & --- & 41 & 40 \\
\hline & D3 & -- & --- & --- & -- & 32 & 40 \\
\hline \multirow[t]{4}{*}{$2000 / 01$} & $\mathrm{~T}$ & 30 & 120 & 50 & --. & 50 & 40 \\
\hline & D1 & --- & --- & --- & --- & 5 & 40 \\
\hline & D2 & --- & --- & 16 & --- & 39 & 40 \\
\hline & D3 & --. & --. & --- & --- & 28 & 40 \\
\hline \multirow[t]{4}{*}{$2001 / 02$} & $\mathrm{~T}$ & 30 & 140 & 50 & --- & 50 & 40 \\
\hline & D1 & --- & --- & --- & --- & --- & 40 \\
\hline & D2 & --- & --- & --- & --- & 34 & 40 \\
\hline & D3 & --- & --- & --- & --- & 17 & 40 \\
\hline
\end{tabular}

T-Control treatment; D1-treatment with 2.5 or $20 \mathrm{t} \mathrm{ha}^{-1}$ of biosolids; D2- treatment with $5.0 \mathrm{t}$ ha ${ }^{-1}$ of biosolids; D3- treatment with $10.0 \mathrm{t}$ ha ${ }^{-1}$ of biosolids. 
Table 6 - Mean contents of total heavy metals in soils after five years of biosolids application.

\begin{tabular}{|c|c|c|c|c|}
\hline \multirow{2}{*}{ Biosolids } & \multicolumn{2}{|c|}{ TH } & \multicolumn{2}{|c|}{ TE } \\
\hline & $0-20 \mathrm{~cm}$ & $20-40 \mathrm{~cm}$ & $0-20 \mathrm{~cm}$ & $20-40 \mathrm{~cm}$ \\
\hline \multicolumn{5}{|l|}{$\mathrm{t} \mathrm{ha}^{-1}$} \\
\hline \multicolumn{5}{|c|}{ Copper (mg kg-1) } \\
\hline 0.0 & $4.78 \mathrm{Ca}$ & $4.73 \mathrm{Ba}$ & $63.55 \mathrm{Aa}$ & $61.87 \mathrm{ABa}$ \\
\hline 25.0 & $8.56 \mathrm{Ba}$ & $5.52 \mathrm{Bb}$ & $64.60 \mathrm{Aa}$ & $59.09 \mathrm{Ba}$ \\
\hline 47.5 & $9.78 \mathrm{ABa}$ & $5.89 \mathrm{Ab}$ & $68.12 \mathrm{Aa}$ & $64.57 \mathrm{ABa}$ \\
\hline 50.0 & $11.94 \mathrm{Aa}$ & $6.71 \mathrm{Ab}$ & $69.37 \mathrm{Aa}$ & $69.87 \mathrm{Aa}$ \\
\hline \multicolumn{5}{|c|}{ Manganese (mg kg-1) } \\
\hline 0.0 & $142.20 \mathrm{Aa}$ & $148.67 \mathrm{Aa}$ & $688.95 \mathrm{Aa}$ & $618.15 \mathrm{Ab}$ \\
\hline 25.0 & $143.08 \mathrm{Aa}$ & 135.54 Aa & $669.40 \mathrm{Aa}$ & $650.80 \mathrm{Aa}$ \\
\hline 47.5 & $143.58 \mathrm{Aa}$ & 129.86 Аа & $690.60 \mathrm{Aa}$ & $649.60 \mathrm{Ab}$ \\
\hline 50.0 & $138.35 \mathrm{Aa}$ & $133.35 \mathrm{Aa}$ & $670.05 \mathrm{Aa}$ & $669.70 \mathrm{Aa}$ \\
\hline \multicolumn{5}{|c|}{ Zinc $\left(\mathrm{mg} \mathrm{kg}^{-1}\right)$} \\
\hline 0.0 & $8.22 \mathrm{Ba}$ & $6.54 \mathrm{Ca}$ & $56.17 \mathrm{Ba}$ & $52.79 \mathrm{Ba}$ \\
\hline 25.0 & $27.58 \mathrm{ABa}$ & $17.74 \mathrm{Ab}$ & $66.24 \mathrm{ABa}$ & $53.45 \mathrm{Bb}$ \\
\hline 47.5 & $20.53 \mathrm{ABa}$ & $11.26 \mathrm{Bb}$ & $80.36 \mathrm{Aa}$ & $61.94 \mathrm{ABb}$ \\
\hline 50.0 & $28.98 \mathrm{Aa}$ & $14.22 \mathrm{ABb}$ & $84.07 \mathrm{Aa}$ & $67.53 \mathrm{Ab}$ \\
\hline \multicolumn{5}{|c|}{ Lead $\left(\mathrm{mg} \mathrm{kg}^{-1}\right)$} \\
\hline 0.0 & $8.54 \mathrm{Ca}$ & $9.11 \mathrm{Ba}$ & $16.96 \mathrm{ABa}$ & $15.80 \mathrm{Aa}$ \\
\hline 25.0 & $9.81 \mathrm{ABa}$ & $9.42 \mathrm{ABa}$ & $17.68 \mathrm{ABa}$ & $15.43 \mathrm{Aa}$ \\
\hline 47.5 & $9.50 \mathrm{Ba}$ & $9.82 \mathrm{ABa}$ & $16.44 \mathrm{Ba}$ & $15.06 \mathrm{Aa}$ \\
\hline 50.0 & $10.45 \mathrm{Aa}$ & $10.20 \mathrm{Aa}$ & $18.20 \mathrm{Aa}$ & $15.75 \mathrm{Aa}$ \\
\hline \multicolumn{5}{|c|}{ Nickel $\left(\mathrm{mg} \mathrm{kg}^{-1}\right)$} \\
\hline 0.0 & $4.23 \mathrm{Ca}$ & $4.51 \mathrm{Ba}$ & $13.34 \mathrm{Ba}$ & $12.44 \mathrm{Aa}$ \\
\hline 25.0 & $6.41 \mathrm{Ba}$ & $5.07 \mathrm{ABb}$ & $15.83 \mathrm{Aa}$ & $14.02 \mathrm{Ab}$ \\
\hline 47.5 & $5.74 \mathrm{Ba}$ & $5.03 \mathrm{ABa}$ & $14.29 \mathrm{ABa}$ & $12.37 \mathrm{Ab}$ \\
\hline 50.0 & $7.12 \mathrm{Aa}$ & $5.59 \mathrm{Ab}$ & $16.03 \mathrm{Aa}$ & $13.88 \mathrm{Ab}$ \\
\hline
\end{tabular}

Means followed by the same letters are not different by the Tukey's test $(P<0.05)$. Capital letters compare means in the same column and for the same element and small letters compare means in the same line and for the same soil.

\section{Heavy metal accumulation in maize plants}

Metal contents were higher in shoots than in grain (Table 7). Similar results were observed by Miller et al. (1995) in an experiment with barley where the contents of $\mathrm{Cd}, \mathrm{Zn}, \mathrm{Cu}$ and $\mathrm{Ni}$ were higher in straw that in grain. Maize shoots and grains cropped in TH contained lower $\mathrm{Cu}, \mathrm{Zn}$ and $\mathrm{Mn}$ concentrations than those cropped in TE. Only for $\mathrm{Pb}$ and $\mathrm{Ni}$ higher concentrations were found in plants cultivated in the $\mathrm{TH}$, a sandy soil that facilitates uptake of these elements by plants.

The concentration of $\mathrm{Pb}$ in grain from both soils and $\mathrm{Ni}$ from the TE was below detection limit of the method. The transfer of $\mathrm{Pb}$ from soils to roots, shoots, fruits and seeds is usually low but, sometimes, can be significant (Chaney, 1989). Lead concentrations are generally much less than $1 \mathrm{mg} \mathrm{kg}^{-1}$ in fruits and grains, and 1 to $3 \mathrm{mg} \mathrm{kg}^{-1}$ in leaves (Wallace \& Wallace, 1994). In general, concentration of heavy metals in maize plants was not affected by increasing rates of biosolids. Oliveira et al. (2002) showed that $\mathrm{Cd}, \mathrm{Cr}, \mathrm{Ni}$ and $\mathrm{Pb}$ concentrations in sugarcane leaves, stalks and juice were also below the detection limit of the methodology used, and that $\mathrm{Cu}$ and $\mathrm{Zn}$ contents in plants were not affected by successive waste compost applications. Melo et al. (2002) and Anjos \& Mattiazzo (2000) corroborate those findings. Values obtained in this experiment did not exceed limits considered toxic for maize plants: $6-20 \mathrm{mg} \mathrm{kg}^{-1}$ for $\mathrm{Cu}, 225-$ $1200 \mathrm{mg} \mathrm{kg}^{-1}$ for $\mathrm{Mn}$ and $15-50 \mathrm{mg} \mathrm{kg}^{-1}$ for $\mathrm{Zn}$ (Malavolta, 1994; Raij et al., 1996).

\section{Mehlich 1 extractant for evaluating heavy metal avail- ability to maize}

Concentrations of $\mathrm{Cu}, \mathrm{Ni}, \mathrm{Pb}$ and $\mathrm{Zn}$ in the Mehlich 1 extract (Table 8) increased with increasing rates of biosolids in the $\mathrm{TH}$; regarding $\mathrm{Mn}$, there was no relationship between extractability and the biosolids rate. 
Baxter et al (1983) observed similar results for $\mathrm{Cu}, \mathrm{Cr}$ and $\mathrm{Zn}$ extracted with DTPA and Mehlich 3. In the TE, the Mehlich 1 extract concentrations of $\mathrm{Ni}$ in both depths, and of $\mathrm{Zn}, \mathrm{Cu}$ and $\mathrm{Mn}$ in the $0-20 \mathrm{~cm}$ depth, increased with the increasing rates of biosolids. However, the $\mathrm{Pb}$ extract concentration was not affected.

Chang et al. (1984) found that biosolids application at the rate $90 \mathrm{t} \mathrm{ha}^{-1}$ year $^{-1}$ for six years increased the concentrations of $\mathrm{Cd}, \mathrm{Cr}, \mathrm{Cu}, \mathrm{Ni}$ and $\mathrm{Zn}$ extracted by 4 mol L ${ }^{-1} \mathrm{HNO}_{3}$ solution. Martins et al. (2003) observed that increasing sewage sludge rates induced a linear increase in the $\mathrm{Ni}, \mathrm{Cu}$ and $\mathrm{Zn}$ concentrations of soil extracts obtained with DTPA and Mehlich 3. Balkcom et al. (2001) found that extractable $\mathrm{Cu}$ and $\mathrm{Zn}$ increased with sludge application rate, while sludge had no effect on Mn. DTPA extractor is more efficient to estimate the availability of

Table 7 - Total contents of heavy metals in maize plant in the Typic Haplorthox (TH) and in the Typic Eutrorthox (TE) in the fifth year of experimentation.

\begin{tabular}{|c|c|c|c|c|}
\hline \multirow{2}{*}{ Biosolids } & \multicolumn{2}{|c|}{ TH } & \multicolumn{2}{|c|}{ TE } \\
\hline & Shoot & Grain & Shoot & Grain \\
\hline \multicolumn{5}{|l|}{$\mathrm{t} \mathrm{ha}^{-1}$} \\
\hline \multicolumn{5}{|c|}{ Copper $\left(\mathrm{mg} \mathrm{kg}^{-1}\right)$} \\
\hline 0.0 & $1.85 \mathrm{~A}$ & $1.12 \mathrm{~A}$ & $3.35 \mathrm{~A}$ & $1.14 \mathrm{~A}$ \\
\hline 25.0 & $1.81 \mathrm{~A}$ & $1.30 \mathrm{~A}$ & $3.06 \mathrm{~A}$ & $1.30 \mathrm{~A}$ \\
\hline 47.5 & $1.65 \mathrm{~A}$ & $0.95 \mathrm{~A}$ & $3.68 \mathrm{~A}$ & $1.33 \mathrm{~A}$ \\
\hline 50.0 & $1.63 \mathrm{~A}$ & $1.27 \mathrm{~A}$ & $3.00 \mathrm{~A}$ & $1.34 \mathrm{~A}$ \\
\hline \multicolumn{5}{|c|}{ Zinc $\left(\mathrm{mg} \mathrm{kg}^{-1}\right)$} \\
\hline 0.0 & $9.69 \mathrm{~B}$ & $11.76 \mathrm{~B}$ & $16.09 \mathrm{~B}$ & $16.60 \mathrm{~A}$ \\
\hline 25.0 & $12.06 \mathrm{~B}$ & $16.29 \mathrm{AB}$ & $15.18 \mathrm{~B}$ & $14.60 \mathrm{~A}$ \\
\hline 47.5 & $19.79 \mathrm{~A}$ & $15.25 \mathrm{~A}$ & $34.25 \mathrm{~A}$ & $21.65 \mathrm{~A}$ \\
\hline 50.0 & $12.43 \mathrm{~B}$ & $17.19 \mathrm{~A}$ & $18.16 \mathrm{~B}$ & $16.33 \mathrm{~A}$ \\
\hline \multicolumn{5}{|c|}{ Manganese $\left(\mathrm{mg} \mathrm{kg}^{-1}\right)$} \\
\hline 0.0 & $22.70 \mathrm{~A}$ & $4.14 \mathrm{~A}$ & $22.12 \mathrm{~B}$ & $3.57 \mathrm{~A}$ \\
\hline 25.0 & $13.91 \mathrm{~B}$ & $4.27 \mathrm{~A}$ & $19.39 \mathrm{~B}$ & $3.24 \mathrm{~A}$ \\
\hline 47.5 & $14.44 \mathrm{~B}$ & $3.27 \mathrm{~A}$ & $29.28 \mathrm{~A}$ & $4.20 \mathrm{~A}$ \\
\hline 50.0 & $9.67 \mathrm{C}$ & $3.87 \mathrm{~A}$ & $19.61 \mathrm{~B}$ & $3.55 \mathrm{~A}$ \\
\hline \multicolumn{5}{|c|}{ Lead $\left(\mathrm{mg} \mathrm{kg}^{-1}\right)$} \\
\hline 0.0 & $2.17 \mathrm{~A}$ & $<\mathrm{DL}$ & $0.16 \mathrm{~A}$ & $<\mathrm{DL}$ \\
\hline 25.0 & $1.93 \mathrm{~A}$ & $<\mathrm{DL}$ & $0.12 \mathrm{~A}$ & $<\mathrm{DL}$ \\
\hline 47.5 & $1.87 \mathrm{~A}$ & $<\mathrm{DL}$ & $0.22 \mathrm{~A}$ & $<\mathrm{DL}$ \\
\hline 50.0 & $2.06 \mathrm{~A}$ & $<\mathrm{DL}$ & $0.53 \mathrm{~A}$ & $<\mathrm{DL}$ \\
\hline \multicolumn{5}{|c|}{ Nickel (mg kg-1) } \\
\hline 0.0 & $1.15 \mathrm{~A}$ & $0.46 \mathrm{~A}$ & $0.65 \mathrm{~A}$ & $<\mathrm{DL}$ \\
\hline 25.0 & $1.22 \mathrm{~A}$ & $0.18 \mathrm{~A}$ & $0.71 \mathrm{~A}$ & $<\mathrm{DL}$ \\
\hline 47.5 & $0.97 \mathrm{~A}$ & $0.16 \mathrm{~A}$ & $0.93 \mathrm{~A}$ & $<\mathrm{DL}$ \\
\hline 50.0 & $1.15 \mathrm{~A}$ & $0.27 \mathrm{~A}$ & $0.90 \mathrm{~A}$ & $<\mathrm{DL}$ \\
\hline
\end{tabular}

$\mathrm{DL}=$ detection limit. Means followed by the same letters in the same column and for the same element are not different by the Tukey's test $(P<0.05)$. heavy metals to plants than the Mehlich 1 extractor, and only Mn availability is efficiently estimated by DTPA in both sandy and clayey soils (Mantovani et al., 2004)

In general, the Mehlich 1 extractant was ineffective to evaluate the availability of the studied heavy metals $(\mathrm{Cu}, \mathrm{Ni}, \mathrm{Mn}, \mathrm{Pb}$ and $\mathrm{Zn})$ to maize plant in both soils (Table 9). Values of the correlation coefficients were low and not significant for $\mathrm{Mn}, \mathrm{Ni}(\mathrm{r}=-0.36 ; \mathrm{r}=-0.27$; respectively).

Table 8 - Contents of heavy metals extracted by Mehlich 1 in the two soils.

\begin{tabular}{|c|c|c|c|c|c|}
\hline Biosolids & $\mathrm{Cu}$ & $\mathrm{Mn}$ & $\mathrm{Ni}$ & $\mathrm{Pb}$ & $\mathrm{Zn}$ \\
\hline $\mathrm{t} \mathrm{ha}^{-1}$ & \multicolumn{5}{|c|}{ - $\mathrm{mg} \mathrm{kg}^{-3}$} \\
\hline \multicolumn{6}{|c|}{ Typic Haplorthox } \\
\hline \multicolumn{6}{|c|}{$0-20 \mathrm{~cm}$} \\
\hline 0.0 & $1.84 \mathrm{c}$ & $67.69 \mathrm{a}$ & $0.26 \mathrm{c}$ & $1.14 \mathrm{c}$ & $0.36 \mathrm{~b}$ \\
\hline 25.0 & $5.12 \mathrm{~b}$ & $73.81 \mathrm{a}$ & $1.73 \mathrm{~b}$ & $1.58 \mathrm{~b}$ & $1.71 \mathrm{a}$ \\
\hline 47.5 & $5.47 \mathrm{~b}$ & 69.72 a & $2.10 \mathrm{~b}$ & $1.48 \mathrm{~b}$ & $2.07 \mathrm{a}$ \\
\hline 50.0 & $8.41 \mathrm{a}$ & $76.36 \mathrm{a}$ & $3.04 \mathrm{a}$ & $2.01 \mathrm{a}$ & $2.78 \mathrm{a}$ \\
\hline \multicolumn{6}{|c|}{$20-40 \mathrm{~cm}$} \\
\hline 0.0 & $1.31 \mathrm{~b}$ & $33.06 \mathrm{a}$ & $0.14 \mathrm{~b}$ & $0.94 \mathrm{~b}$ & $0.21 \mathrm{c}$ \\
\hline 25.0 & $2.10 \mathrm{ab}$ & 34.98 a & $0.48 \mathrm{ab}$ & $1.11 \mathrm{ab}$ & $0.80 \mathrm{bc}$ \\
\hline 47.5 & $2.46 \mathrm{ab}$ & $33.09 \mathrm{a}$ & $0.50 \mathrm{ab}$ & $1.28 \mathrm{a}$ & $1.10 \mathrm{ab}$ \\
\hline 50.0 & $3.25 \mathrm{a}$ & $35.79 \mathrm{a}$ & $0.92 \mathrm{a}$ & $1.25 \mathrm{ab}$ & $1.61 \mathrm{a}$ \\
\hline \multicolumn{6}{|c|}{ Typic Eutrorthox } \\
\hline \multicolumn{6}{|c|}{$0-20 \mathrm{~cm}$} \\
\hline 0.0 & $12.89 \mathrm{~b}$ & $79.13 \mathrm{a}$ & $0.80 \mathrm{~b}$ & $0.27 \mathrm{a}$ & $1.44 \mathrm{~b}$ \\
\hline 25.0 & $14.75 \mathrm{ab}$ & $99.80 \mathrm{a}$ & $1.64 \mathrm{~b}$ & $0.28 \mathrm{a}$ & $3.84 \mathrm{ab}$ \\
\hline 47.5 & $17.64 \mathrm{a}$ & $99.08 \mathrm{a}$ & $2.97 \mathrm{a}$ & $0.29 \mathrm{a}$ & $5.56 \mathrm{a}$ \\
\hline 50.0 & $18.74 \mathrm{a}$ & $113.84 \mathrm{a}$ & $3.19 \mathrm{a}$ & $0.43 \mathrm{a}$ & $5.51 \mathrm{a}$ \\
\hline \multicolumn{6}{|c|}{$20-40 \mathrm{~cm}$} \\
\hline 0.0 & $13.38 \mathrm{a}$ & $49.28 \mathrm{a}$ & $0.37 \mathrm{~b}$ & $0.20 \mathrm{a}$ & $4.53 \mathrm{a}$ \\
\hline 25.0 & $12.76 \mathrm{a}$ & $60.93 \mathrm{a}$ & $0.57 \mathrm{~b}$ & $0.25 \mathrm{a}$ & $4.82 \mathrm{a}$ \\
\hline 47.5 & $13.98 \mathrm{a}$ & $53.70 \mathrm{a}$ & $0.98 \mathrm{a}$ & $0.25 \mathrm{a}$ & $5.84 \mathrm{a}$ \\
\hline 50.0 & $15.39 \mathrm{a}$ & $62.58 \mathrm{a}$ & $1.04 \mathrm{a}$ & $0.22 \mathrm{a}$ & $6.42 \mathrm{a}$ \\
\hline
\end{tabular}

Means followed by the same letters in the same column and for the same depth are not different by the Tukey's test $(P<0.05)$.

Table 9 - Linear correlations between heavy metals content in maize parts plant and heavy metals extracted by Mehlich 1 extractant in soil samples obtained at 0-20 cm depth.

\begin{tabular}{lrrrrc}
\hline Part of plant & $\mathrm{Cu}$ & $\mathrm{Mn}$ & $\mathrm{Ni}$ & $\mathrm{Pb}$ & $\mathrm{Zn}$ \\
\hline \multicolumn{7}{c}{ Typic Haplorthox } \\
\hline Plant shoot & $-0.48^{*}$ & -0.23 & -0.07 & 0.03 & 0.43 \\
Grain & 0.20 & 0.36 & -0.25 & nd & 0.39 \\
\hline \multicolumn{7}{c}{ Typic Eutrorthox } \\
\hline Plant shoot & 0.02 & -0.17 & 0.36 & -0.16 & $0.48^{*}$ \\
Grain & -0.12 & 0.11 & nd & nd & $0.37^{*}$ \\
\hline
\end{tabular}

*Significant at $(P<0.05)$.

nd $=$ not determined 
Abreu et al. (1994) reported that correlations between soybean $\mathrm{Mn}$ and soil Mn were not significant for the Mehlich 1 extractor. Abreu et al. (1995) observed, in pot experiment, that Mehlich 1, Mehlich 3 and DTPA were ineffective for evaluating availability of $\mathrm{Pb}$ and $\mathrm{Ni}$ to wheat plants, and $\mathrm{Pb}$ to bean plants.

Significant correlations were found only for extractable soil $\mathrm{Zn}$ and its concentration in grain and shoot of maize plants cropped in the TE, and for $\mathrm{Cu}$ in the $\mathrm{TH}$ soil with plant shoots. Korcak \& Fenning (1978) found that the concentrations of $\mathrm{Cd}$ and $\mathrm{Zn}$ in maize plant were correlated with that extracted by Mehlich 1 and DTPA extractants in soils, when there were excessive amounts of these metals. Haq et al. (1980) tested nine extractants (aqua regia, DTPA, NTDA, EDTA, acetic acid, ammonium acetate, $\mathrm{H}_{2} \mathrm{O}$, hydrochloric acid, aluminium chloride) and observed that only Ni had correlation with acetic acid. The efficiency of the Mehlich 1 extractant is quite variable, depending on the metal being evaluated and on the soil type and the plant tested (Pires \& Mattiazzo, 2003).

\section{CONCLUSIONS}

The concentrations of $\mathrm{Cu}, \mathrm{Mn}, \mathrm{Ni}, \mathrm{Pb}$ and $\mathrm{Zn}$ in the $\mathrm{TH}$ and in the TE were below critical limits permitted for agricultural use of biosolids established by USEPA and CETESB. The Mehlich 1 extractant was not efficient for evaluating phytoavailability of $\mathrm{Cu}, \mathrm{Zn}, \mathrm{Mn}, \mathrm{Ni}$ and $\mathrm{Pb}$ to maize plants grown on $\mathrm{TH}$ and $\mathrm{TE}$ amended for five years with biosolids. There was no movement of $\mathrm{Mn}, \mathrm{Ni}, \mathrm{Cu}$ and $\mathrm{Pb}$ down the soil profile and little movement of $\mathrm{Zn}$.

Concentrations of heavy metals were higher in plant shoot than in grains in maize plants.

\section{ACKNOWLEDGEMENT}

To FAPESP for the financial support and $\mathrm{CNPq}$ for scholarship to the first author.

\section{REFERENCES}

ABREU, C.A.; NOVAIS, R.F.; RAIJ, B. van; RIBEIRO, A.C. Influência da reação do solo na extração de manganês por diferentes extratores químicos. Revista Brasileira de Ciência do Solo, v.18, p.91-99, 1994.

ABREU, C.A.; ABREU, M.F.; RAIJ, B. van; SANTOS, W.R. Comparação de métodos de análise para avaliar a disponibilidade de metais pesados em solos. Revista Brasileira de Ciência do Solo, v.19, p.463-468, 1995.

ANDERSON, A.; NILSON, K.O. Enrichment of trace elements from sewage sludge fertilizer in soils and plants. Ambio, v.1, p.176-179, 1972.

ANJOS, A.R.M.; MATTIAZZO, M.E. Metais pesados em plantas de milho cultivadas em Latossolos repetidamente tratados com biossólido. Scientia Agricola, v.57, p.769-776, 2000.

BALKCOM, K.S.; ADAMS, J.F.; HARTZOG, D.L.; WOOD, C.W. Mineralization of composed municipal sludge under field condition. Communications in Soil Science and Plant Analysis, v.32, p.15891605, 2001.

BATAGLIA, O.C.; FURLANI, A.M.C.; TEIXEIRA, J.P.F.; FURLANI, P.R.; GALLO. J.R. Métodos de análises químicas de plantas. Campinas: Instituto Agronômico, 1983. 48p.
BAXTER, J.C.; AGUILAR, M.; BROWN, K. Heavy metals and persistent organics at sewage sludge disposal site. Journal of Environmental Quality, v.12, p.311-316, 1983.

BOSWEL, F.C. Municipal sewage sludge and selected element application to soil: Effect on soil and fescue. Journal of Environmental Quality, v.4, p.267-272, 1975.

CHANEY, R.L. Scientific analysis of proposed sludge rule. BioCycle, v.30, p.80-85, 1989 .

CHANEY, R.L; GIORDANO, P.M. Microelements as related to plant deficiencies and toxicities. In: ELLIOT, L.F.; STEVENSON, F.J. Soils for management of organic wastes and wastewaters. Madison: SSSA, 1977. p.234-279.

CHANG, A.C.; WARNEKE, J.E.; PAGE, A.L.; LUND, L.J. Accumulation of heavy metals in sewage sludge-treated soils. Journal of Environmental Quality, v.13, p.87-91, 1984.

CETESB. Aplicação de lodos de sistema de tratamento biológico em áreas agrícolas para projeto e operação: manual técnico. São Paulo: ABIA, 1999. 32p. (P.4230)

HAQ, A.U.; BATES, T.E.; SOON, Y.K. Comparison of extractors for plantavailable zinc, cadmium and cooper in contaminated soils. Soil Science Society of America Journal, v.44, p.772-777, 1980.

HUE, N.V. Residual effects of sewage sludge application on plant and soilprofile chemical composition. Communications in Soil Science and Plant Analysis, v.19, p.1633-1643, 1988

KORCAK, R.F.; FENNING, D.S. Extractability of cadmium, copper, nickel and zinc by double acid levels. Journal of Environmental Quality, v.7, p.506-512, 1978 .

MALAVOLTA, E. Fertilizantes e seu impacto ambiental: micronutrientes e metais pesados, mitos, mistificação e fatos. São Paulo: Produquímica, 1994. 153p.

MANTOVANI, J.R.; CRUZ, M.C.P.; EVARISTO, M.F.; ALVES, W.L. Extratores para avaliação da disponibilidade de metais pesados em solos adubados com vermicomposto de lixo urbano. Pesquisa agropecuária brasileira, v.39, p.371-378, 2004

MARCHIORI Jr., M. Impacto ambiental da citricultura nos teores de metais pesados em solos do Estado de São Paulo. Jaboticabal: UNESP/FCAV, 2002. (Tese - Doutorado).

MARTINS, A.L.C.; BATAGLIA, O.C.; CAMARGO, O.A. Copper, nickel and zinc phytoavailability in an oxisol amended with sewage sludge and liming. Scientia Agricola, v.60., p.747-754, 2003.

MATTIGOD, S.V.; PAGE, A.L. Assessment of metal pollution in soil. In: THORNTON, I. (Ed.) Applied environmental geochemistry. London: Academic Press, 1983. cap.12, p.355-394.

McBRIDE, M.B. Toxic metal accumulation from agricultural use of sludge: are USEPA regulations protective? Journal of Environmental Quality, v.24, p.5-18, 1995.

McGRATH, S.P.; LANE, P.W. An explanation for the apparent losses of metal in long-term field experiment with sewage sludge. Environmental Pollution, v.60, p.235-256, 1989.

MELO, V.P. Propriedades químicas e disponibilidade de metais pesados para a cultura do milho em dois latossolos que receberam a adição de biossólido. Jaboticabal: UNESP/FCAV, 2002. (Dissertação Mestrado)

MELO, W.J.; MARQUES, M.O.; FERREIRA, M.E.; MELO, G.M.P.; MELO, V.P. Chemical properties and enzyme activity in a sewage sludgetreated soil. Communications in Soil Science and Plant Analysis, v.33, p.1643-1650, 2002.

MILLER, R.W; AZZARI, D.T; GARDINER, D.T. Heavy metals in crops as affected by soil types and sewage sludge rates. Communications in Soil Science and Plant Analysis, v.26, p.703-711,1995.

OLIVEIRA, F.C. Disposição de lodo de esgoto e composto de lixo urbano num Latossolo Vermelho Amarelo cultivado com cana-de-açúcar. Piracicaba: USP/ESALQ, 2000. 247p. (Tese - Doutorado).

OLIVEIRA, F.C.; MATTIAZZO, M.E. Metais pesados em Latossolo tratado com lodo de esgoto e em plantas de cana-de-açúcar. Scientia Agricola, v.58, p.581-593, 2001.

OLIVEIRA, F.C.; MATTIAZZO, M.E.; MARCIANO, C.R.; ABREU, J.C.H. Fitodisponibilidade e teores de metais pesados em um Latossolo amarelo distrófico e em plantas de cana-de-açúcar adubadas com composto de lixo urbano. Revista Brasileira de Ciência do Solo, v.26, p.737-746, 2002 .

Sci. Agric. (Piracicaba, Braz.), v.62, n.4, p.381-388, July/Aug. 2005 
PARKER, G.R.; Mc FEE, W.W.; KELLY, J.M. Metal distribution in forested ecosystem in urban and rural northwester Indiana. Journal of Environmental Quality, v.7, p.337-342, 1978.

PIRES, A.M.M.; MATTIAZZO, M.E. Biosolid conditioning and the availability of $\mathrm{Cu}$ and $\mathrm{Zn}$ for rice. Scientia Agricola, v.60, p.161-166, 2003.

RAIJ, B. van; CANTARELLA, H.; QUAGGIO, J.A.; FURLANI, A.M.C. Recomendações de adubação e calagem para o Estado de São Paulo. Campinas, Instituto Agronômico, 1996. 285p. (Boletim Técnico, 100).

SIDLE, R.C.; HOOK, J.E.; KARDOS, L.T. Heavy metals application and plant uptake in a land disposal system for wastewater. Journal of Environmental Quality, v.5, p.97-102, 1976.

SILVEIRA, M.L.A.; ALLEONI, L.R.F.; GUILHERME, L.R.G. Biosolids and heavy metals in soils. Scientia Agricola, v.60, p.793-806, 2003.
UNITED STATES ENVIRONMENTAL PROTECTION AGENCY. A guide to the biosolids risk assessment for the EPA. Part 503 rules. Cincinnati: USEPA, 1995. (EPA/832-B-93-005).

UNITED STATES ENVIRONMENTAL PROTECTION AGENCY. Standards for the use and disposal sewage sludge. Washington: USEPA, 1986. (Code of Federal Regulations 40 CRF Part 503).

WALLACE, G.A.; WALLACE. A. Lead and other potentially toxic heavy metals in soil. Communications in Soil Science and Plant Analysis, v.25, p.137-141, 1994.

Received November 19, 2004

Accepted June 10, 2005 